\section{Effect of Irrigation Pattern and Timing on Root Density of Young Citrus Trees Infected with Huanglongbing Disease}

\author{
Davie M. Kadyampakeni ${ }^{1,4}$, Kelly T. Morgan ${ }^{1}$, \\ Arnold W. Schumann ${ }^{2}$, and Peter Nkedi-Kizza ${ }^{3}$
}

AdDitional Index words. Candidatus Liberibacter asiaticus, Citrus sinensis, open hydroponics system, root length density

Summary. Citrus (Citrus sp.) root length density (RLD) can help in understanding and predicting nutrient and water uptake dynamics. A study was conducted at two sites in Florida to investigate root and water distribution patterns among different irrigation and fertigation systems. The results over the 2 years showed that RLD was highest in the 0 - to $15-\mathrm{cm}$ soil depth and decreased with depth for all treatments at both sites. About $64 \%$ to $82 \%$ of the fibrous roots $(<1 \mathrm{~mm}$ diameter) were concentrated in the irrigated zones of drip- and microsprinkler-irrigated trees and $18 \%$ to $36 \%$ were found in the nonirrigated zones at the Spodosol site (SS). At the Entisol site (ES), the RLD ( $<0.5 \mathrm{~mm}$ diameter) in the 0 - to $15-\mathrm{cm}$ depth soil for intensive microsprinkler or drip irrigation was 3- to 4-fold (nonirrigated zone) and 4- to 7 -fold (irrigated zone) greater at the 0 - to $15-\mathrm{cm}$ soil depth than that for conventional irrigation system. The trees at SS were symptomatic for Huanglongbing (HLB; Candidatus Liberibacter asiaticus) in the second year, while those at ES were asymptomatic throughout the study. This might have limited the density and extent of root distribution at SS. The water contents remained either close to or slightly above the field capacity. The results showed higher RLD for intensive irrigation and fertigation practices in irrigated zones compared with conventional grower applications suggesting greater water and nutrient uptake potential for the former.

$\mathrm{U}$ nderstanding citrus root distribution is critical for predicting potential pathways of water and nutrient uptake. Studies conducted in Florida over the past 40 years have shown that tree size and yield were intrinsically linked to root density distribution (Castle and Krezdorn, 1975; Eissenstat, 1991; Morgan et al., 2006, 2007). Research has shown that citrus rootstocks with the greater root weight or RLD resulted in greatest water

The authors would like to thank the Southwest Florida Water Management District and University of Florida Institute of Food and Agricultural Sciences for funding this research and GAPWAY Groves Inc. for providing the second site near Lake Alfred for the study.

We would like to thank Dr. Ashok Alva of USDA-ARS and Dr. Nicholas Comerford of the University of Florida for the useful suggestions to our manuscript. We are also grateful for the help from Ms. Laura Waldo, Mr. Shengsen Wang and Ms. Smita Barkataky during data collection.

${ }^{1}$ Southwest Florida Research and Education Center, University of Florida, 2685 SR 29N, Immokalee, FL 34142

${ }^{2}$ Citrus Research and Education Center, University of Florida, 700 Experiment Station Road, Lake Alfred, FL 33850

${ }^{3}$ Soil and Water Science Department, University of Florida, 2181 McCarty Hall, P.O. Box 110290 , Gainesville, FL 32611

${ }^{4}$ Corresponding author. E-mail: dkadyampakeni@ufl. edu. extraction rates from the soil occupied by the roots (Castle, 1980; Castle and Krezdorn, 1975; Eissenstat, 1991; Morgan et al., 2006, 2007). Coleman (2007) observed that RLD of woody crops was dependent upon tree age, soil depth, and position relative to drip emitter when fertilizers were applied and was greatest at the surface and in proximity to the drip line. Abrisqueta et al. (2008) studied root dynamics of young peach (Prunus persica) trees subjected to partial root zone drying and continuous deficit irrigation in Spain. Root length densities were greater in nonlimiting irrigation conditions than those under deficit irrigation where root growth was reduced.

Current citrus fertigation/ fertilization practices in Florida are infrequent and thus, low intensity (Alva et al., 2003, 2006; Koo, 1980). The conditions under which intensive fertigation practices work in Florida citrus producing regions dominated by well-drained sandy soils (Obreza and Collins, 2008) have only recently been investigated (Morgan et al., 2009; Schumann et al., 2009). Intensive fertigation practices are being devised primarily to manage HLB disease and increase yields so growers break-even within a few years of establishing a grove. Graham et al. (2013) found that HLB-infected trees had up to $40 \%$ root loss to bacterial infection of roots with potential additional root loss because of the interaction with the root pathogen Phytophora nicotianae depending on grove location.

This study evaluated intensive fertigation practices already in use in citrus production systems in Australia, Chile, South Africa, and Spain (Carrasco et al., 2003; Kruger et al., 2000a, 2000b; Martinez-Valero and Fernandez, 2004) modified for Florida sandy soils. Thus, knowledge of RLD distribution in response to the patterns of water and nutrient application in the citrus root zone may guide the citrus growers and researchers in optimization of irrigation and fertigation practices. Past root density studies in Florida have concentrated on mature trees older than 5 years (Alva and Syvertsen, 1991; Castle and Krezdorn, 1975; Eissenstat, 1991; Mattos et al., 2003; Morgan et al., 2006, 2007). Thus, this study was conducted to determine RLD and water distribution associated with young trees subject to intensive fertigation management with low volume irrigation and the interaction with the damaging effect of HLB on fibrous roots. The objectives of the study were to 1 ) determine RLD of 1 - and 3-year-old citrus trees; 2) compare the distribution of RLD and water as a function of time, distance from the tree, soil depth and fertigation

\begin{tabular}{llll}
\hline $\begin{array}{l}\text { Units } \\
\text { To convert U.S. to SI, } \\
\text { multiply by }\end{array}$ & U.S. unit & SI unit & $\begin{array}{l}\text { To convert SI to U.S., } \\
\text { multiply by }\end{array}$ \\
\hline 0.3048 & $\mathrm{ft}$ & $\mathrm{m}$ & 3.2808 \\
2.54 & inch $(\mathrm{es})$ & $\mathrm{cm}$ & 0.3937 \\
25.4 & inch $(\mathrm{es})$ & $\mathrm{mm}$ & 0.0394 \\
0.1550 & inch $/ \mathrm{inch}^{3}$ & $\mathrm{~cm} \cdot \mathrm{cm}^{-3}$ & 6.4516 \\
16.3871 & inch & $\mathrm{cm}$ & 0.0610 \\
1 & meq $/ 100 \mathrm{~g}$ & $\begin{array}{ll}3 \\
\mathrm{cmol} \cdot \mathrm{kg}^{-1}\end{array}$ & 1 \\
1.7300 & oz $/ \mathrm{inch}^{3}$ & $\mathrm{~g} \cdot \mathrm{cm}^{-3}$ & 0.5780
\end{tabular}


method; and 3) determine differences between the two sites associated with the presence of citrus greening.

\section{Materials and methods}

Site Conditions. The study was conducted at two sites 1 ) a site at the University of Florida, Southwest Florida Research and Education Center, Immokalee, FL (lat. $26^{\circ} 25^{\prime} \mathrm{N}$, long. $81^{\circ} 25^{\prime} \mathrm{W}$ ) with a Spodosol classified as Immokalee fine sand (sandy, siliceous, hyperthermic Arenic Haplaquods) with an excessively drained upper horizon and a low conductivity horizon at less than $1 \mathrm{~m}$ from the surface (SS) and 2) a site near the Citrus Research and Education Center, Lake Alfred, FL (lat. $28^{\circ} 5^{\prime} \mathrm{N}$, long. $81^{\circ} 45^{\prime} \mathrm{W}$ ) with Candler fine sand (hyperthermic, coated Typic Quartzipsamments) an Entisol excessively drained throughout the profile (ES) (Obreza and Collins, 2008). 'Hamlin' orange (Citrus sinensis) trees on 'Swingle' (Citrus paradisi $\times$ Poncirus trifoliata) rootstock were planted in Apr. 2006 at $10 \times 22 \mathrm{ft}$ on 13.5-m-wide beds with drainage swales at SS. 'Hamlin' orange trees on 'Swingle' and 'C35' (Citrus trifoliata $X$ C. sinensis 'Ruby') rootstocks were planted at $10 \times 20 \mathrm{ft}$ and $8 \times 18 \mathrm{ft}$, respectively, at ES in Dec. 2008.

The soil characteristics for the two sites are described in Table 1. The $\mathrm{pH}$, bulk density, hydraulic conductivities, and moisture contents at saturation and field capacity are similar for the two sites. The two soils are characterized by low organic matter; however, the soil at the ES has 3- to 4 -fold the organic matter at the SS. The cation exchange capacity in the top $0-15 \mathrm{~cm}$ is similar for the two soils, but 2- to 5 -fold greater for ES than SS in the 15- to $45-\mathrm{cm}$ soil depth due to presence of aluminum/iron coatings, and five times greater at SS at 45 - to $60-\mathrm{cm}$ soil depth, due to the spodic soil horizon.

EXPERIMENTAL DESIGN AND IRRIGATION TREATMENTS. Irrigation and fertilizer treatments were as follows: 1) irrigated with selected allowable soil water depletion between irrigations at the two sites but fertigated monthly with $360^{\circ}$ microsprinklers (full-circle microsprinkler) wetting a circle $4.5 \mathrm{~m}$ in diameter at SS and fertilized with soluble materials four to six times per year at ES (Conventional); 2 ) irrigated daily and fertigated weekly

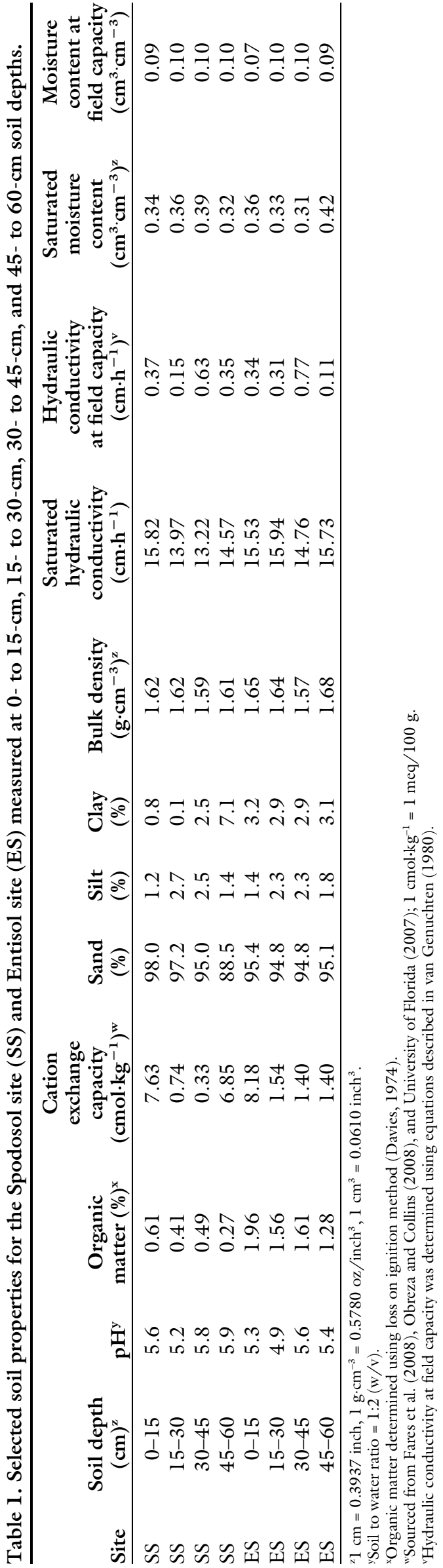

Hortlechnology · April 2014 24(2) 

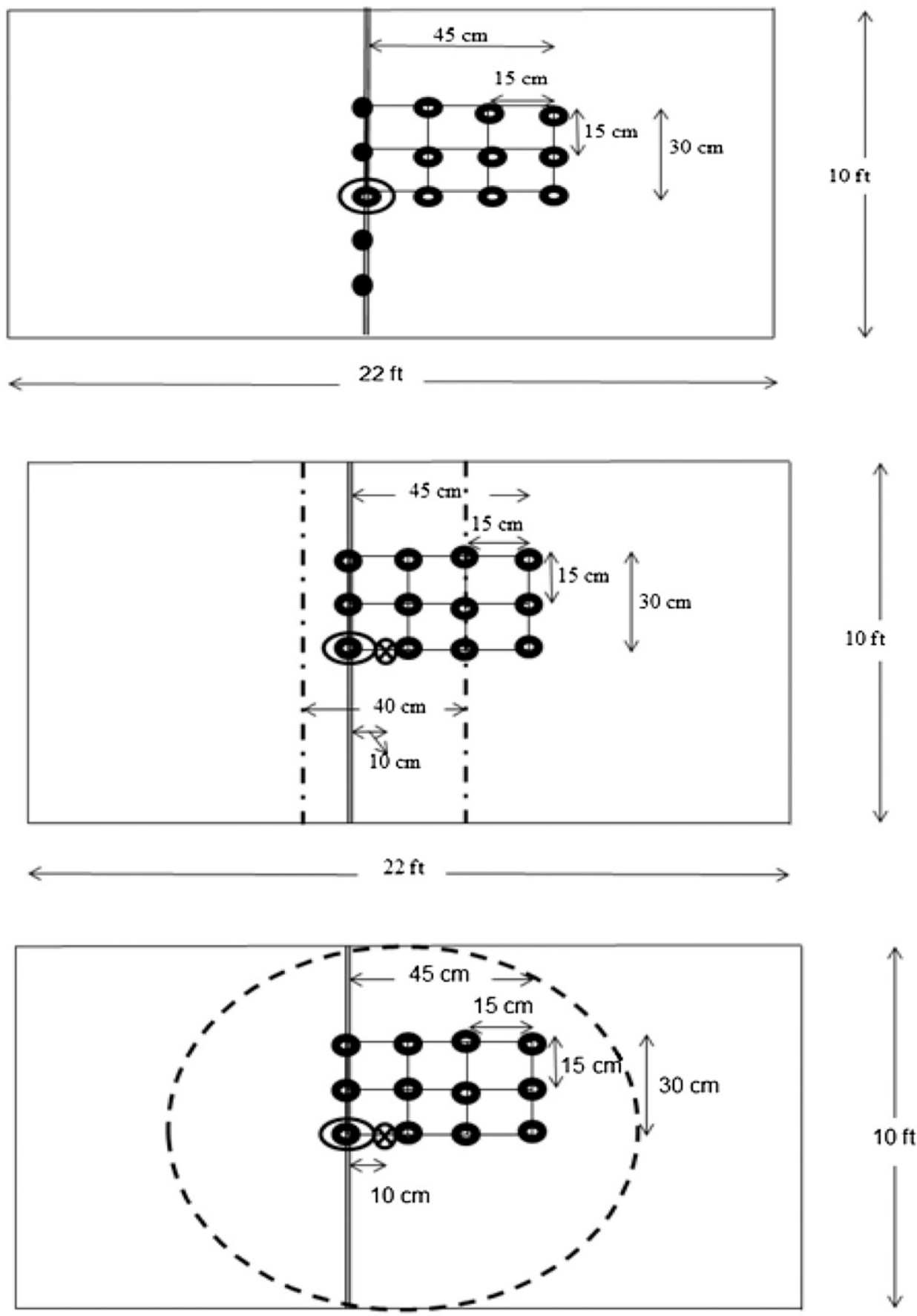

$22 \mathrm{ft}$

$\boldsymbol{O}=$ tree, $\boldsymbol{O}=$ sampling position, $\overline{=}=$ irrigation main line, $\boldsymbol{Q}=$ microsprinkler emitter, spacing between trees $=10 \mathrm{ft}$, row spacing $=22 \mathrm{ft}$.

Fig. 1. A schematic field diagram showing the setup of top-drip irrigation system irrigated and fertigated daily with drip emitters in short pulses (Drip), middle- a modified microsprinkler irrigation system irrigated daily and fertigated weekly with 1-m-wide and 3-m-long wetting pattern microsprinkler (Restricted Microsprinkler), and bottom-conventional microsprinkler irrigation system irrigated with selected allowable soil water depletion between irrigations but fertigated monthly with full-circle microsprinkler (Conventional) at the Spodosol site in 2009. Positions below the dripper within the sampling grid were also sampled and the area between or within the dashed lines was the irrigated zone. All trees were 'Hamlin' orange on 'Swingle' rootstock. The setup for the Entisol site was similar; $1 \mathrm{~m}=3.2808 \mathrm{ft}, 1 \mathrm{ft}=0.3048 \mathrm{~m}, 1 \mathrm{~cm}=0.3937 \mathrm{inch}$. 


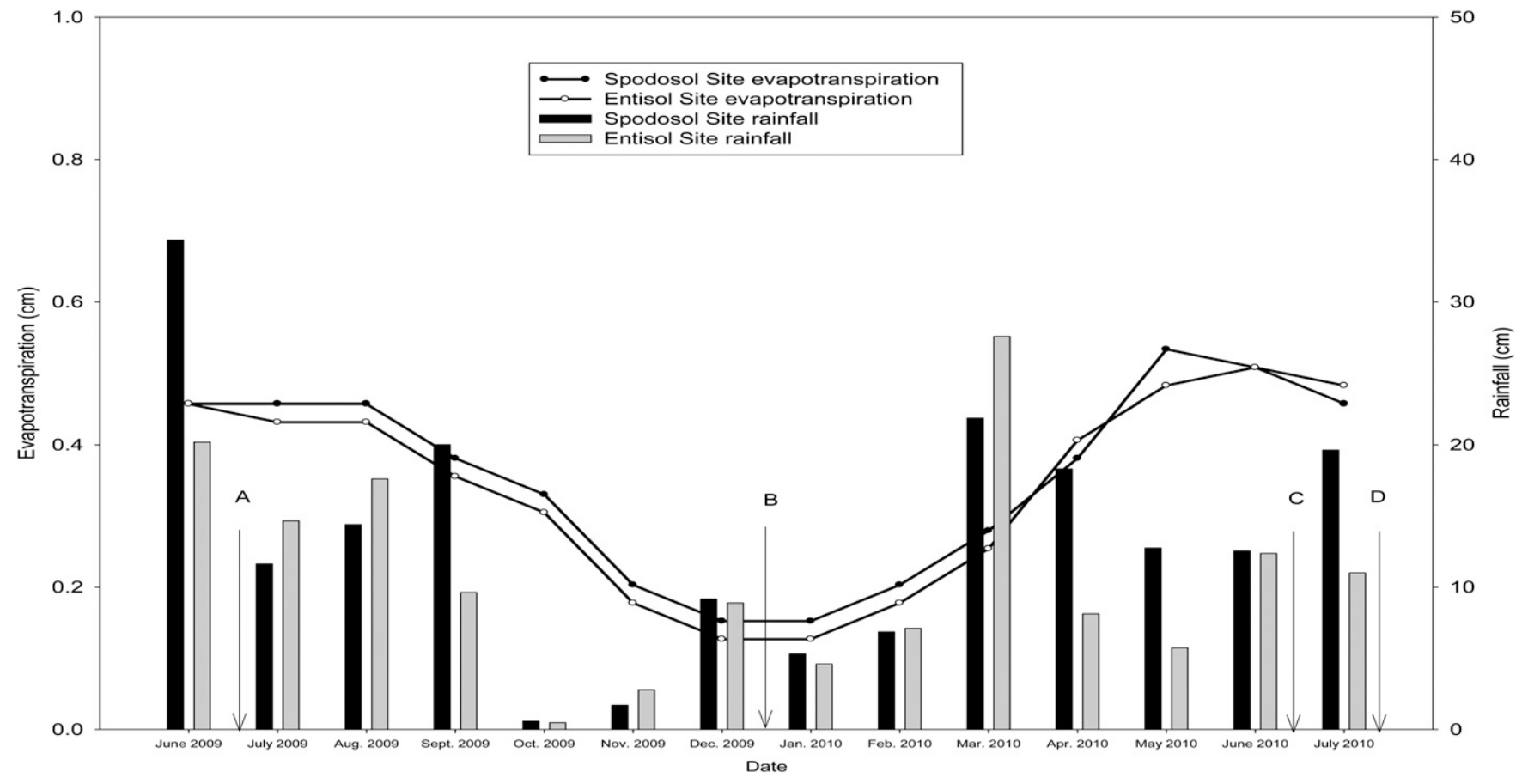

Fig. 2. Evapotranspiration and rainfall at the Spodosol and Entisol sites from 1 June 2009 to 31 July 2010. A and C are the root sampling dates at the Spodosol site, and B and D are the sampling dates for the Entisol site; $1 \mathrm{~cm}=0.3937 \mathrm{inch}$.

with 1 -m-wide and 3-m-long wetting a pattern microsprinkler emitters (Restricted Microsprinkler); and 3) irrigated and fertigated daily with drip emitters in short pulses (Drip). A schematic of the experimental set up is shown in Fig. 1. The SS had one drip line in the first year of the study and two drippers placed on either side of the tree spaced at 15 and $30 \mathrm{~cm}$ from the tree, within the tree row. A second drip line with two drippers placed on either side of the tree was added in the second year of the study. The two drip lines were located $30 \mathrm{~cm}$ from the tree row. At ES, one drip line was placed within the tree row, with one dripper placed at $15 \mathrm{~cm}$ on each side of the tree. All the treatments were laid in a randomized complete block design replicated four times. The trees at SS were symptomatic for HLB in the second year of study (2010), while those of ES were asymptomatic of HLB throughout the study.

Root sAmpling. Root samples were collected at $0-$ to $15-\mathrm{cm}$ and $15-$ to $30-\mathrm{cm}$ depths because most roots of young citrus trees ( $\leq 3$ years old) are concentrated within $30 \mathrm{~cm}$ of the soil surface (Fares and Alva, 2000; Paramasivam et al., 2000; Parsons and Morgan, 2004). Root samples at SS were collected in a $30 \times 45-\mathrm{cm}$ grid in June 2009 and 2010 (Fig. 1).
In 2010, samples were taken at SS from different trees in the same grid locations up to a depth of $45 \mathrm{~cm}$. The samples at ES were collected at four positions in Dec. 2009 and nine positions in July 2010 , in a $15 \times 15-\mathrm{cm}$ and $30 \times 30-\mathrm{cm}$ grid in a single quadrant, respectively, at $0-$ to $15-\mathrm{cm}$, and 15- to 30-cm soil depths. The root sampling method used in the study provides root length estimate in units such as centimeters per cubic centimeter of soil volume based on volume of the auger (Böhm, 1979; Escamilla et al., 1991; Lopez-Zamora et al., 2002).

Roots were removed from the soil using a 2 -mm-diameter sieve and hydrated for $15 \mathrm{~min}$. Hydrated roots were separated into four groups: $<0.5$, $0.5-1.0,1.0-3.0$, and $>3.0 \mathrm{~mm}$ using copper wires of known diameter as a size reference (Kimura and Yamasaki, 2001) before root length determination on a $1.0 \times 1.0-\mathrm{cm}$ grid using the line intersection method (Morgan et al., 2007; Tennant, 1975). RLD for each root category was estimated by multiplying the number of horizontal and vertical root intersections by $11 / 14$ and divided by volume of the auger (Mattos, 2000).

ROOT AREA SCANNING METHOD. The scanning method was used for the above four root size groups of each root sample used for the line intersection method. Image processing software called ImageJ (National Institute of Health, 2009) was used to estimate the surface area covered by the roots on a flatbed scanner (HP4860 Scanjet-G4050; HewlettPackard, Palo Alto, CA). We scanned each root sample three times with roots rearranged between scans resulting in different arrangements to get a better estimation of average root length due to inadvertent overlapping of roots on the scanner by calculating the mean of the three scans. RLD for root samples collected in 2010 were estimated using the regression equations developed from root samples in 2009.

ESTIMATION OF SOIL MOISTURE. Volumetric water content was determined gravimetrically for each soil sample (Hillel, 1998). Rainfall data and other climatic variables were collected from Florida Automated Weather Network stations at Southwest Florida Research and Education Center and Citrus Research and Education Center (Fig. 2) (University of Florida, 2013).

Statistical analysis. The data collected on RLD and water content were analyzed using GLM Mixed Model Type III procedures using SAS (version 9.3 for Windows; SAS Institute, Cary, NC). 
Table 2. Means and analysis of variance (ANOVA) for citrus root length density distribution as a function of irrigation method (Conventional, Drip, and Restricted Microsprinkler irrigation systems), soil depth, and distance from the tree at the Spodosol site on 17 June 2009 and 15 June 2010 in irrigated and nonirrigated zones at $0-$ to $15-\mathrm{cm}, 15-$ to $30-\mathrm{cm}$, and $30-$ to 45-cm soil depths. All trees were 'Hamlin' orange on 'Swingle' rootstock.

\begin{tabular}{|c|c|c|c|c|c|c|c|c|c|}
\hline \multirow[b]{5}{*}{ Irrigation method ${ }^{\mathrm{z}}$} & \multirow[b]{5}{*}{ Depth $(\mathrm{cm})^{\mathrm{y}}$} & \multicolumn{8}{|c|}{$\operatorname{Root} \operatorname{diam}(\mathrm{mm})^{\mathrm{y}}$} \\
\hline & & \multicolumn{2}{|c|}{$<0.5$} & \multicolumn{2}{|c|}{$0.5-1.0$} & \multicolumn{2}{|c|}{$1.0-3.0$} & \multicolumn{2}{|c|}{$>3.0$} \\
\hline & & IRR $^{\mathbf{x}}$ & $\mathrm{NI}^{\mathrm{x}}$ & IRR & NI & IRR & NI & IRR & NI \\
\hline & & \multicolumn{8}{|c|}{17 June 2009} \\
\hline & & \multicolumn{8}{|c|}{ Root length density $\left(\mathrm{cm} \cdot \mathrm{cm}^{-3}\right)^{y}$} \\
\hline Conventional & $0-15$ & 0.154 & $-^{\mathrm{w}}$ & 0.045 & - & 0.018 & - & 0.002 & - \\
\hline Conventional & $15-30$ & 0.105 & - & 0.047 & - & 0.032 & - & 0.005 & - \\
\hline Restricted Microsprinkler & $0-15$ & 0.168 & 0.136 & 0.033 & 0.035 & 0.008 & 0.013 & 0.001 & 0.001 \\
\hline Restricted Microsprinkler & $15-30$ & 0.155 & 0.055 & 0.061 & 0.033 & 0.031 & 0.015 & 0.006 & 0.001 \\
\hline \multicolumn{2}{|l|}{ Source of variation } & \multicolumn{8}{|c|}{ ANOVA } \\
\hline \multicolumn{2}{|l|}{ Irrigation method } & \multicolumn{2}{|c|}{ NS } & \multicolumn{2}{|c|}{$* * *$} & \multicolumn{2}{|c|}{$* * *$} & \multicolumn{2}{|c|}{ NS } \\
\hline \multicolumn{2}{|l|}{ Depth } & \multicolumn{2}{|c|}{$* * *$} & \multicolumn{2}{|c|}{ NS } & \multicolumn{2}{|c|}{ *** } & \multicolumn{2}{|c|}{$* * *$} \\
\hline \multicolumn{2}{|l|}{ Position } & \multicolumn{2}{|c|}{$* * *$} & \multicolumn{2}{|c|}{ NS } & \multicolumn{2}{|c|}{ NS } & \multicolumn{2}{|c|}{ NS } \\
\hline \multicolumn{2}{|l|}{ Irrigation $\times$ depth } & \multicolumn{2}{|c|}{ NS } & \multicolumn{2}{|c|}{ NS } & \multicolumn{2}{|c|}{ NS } & \multicolumn{2}{|c|}{ NS } \\
\hline \multicolumn{2}{|l|}{ Depth $\times$ position } & \multicolumn{2}{|c|}{ NS } & \multicolumn{2}{|c|}{ NS } & \multicolumn{2}{|c|}{ NS } & & \\
\hline Position $\times$ irrigation meth & & & & & & & & & \\
\hline Irrigation method $\times$ dept & osition & & & & & & & & \\
\hline
\end{tabular}

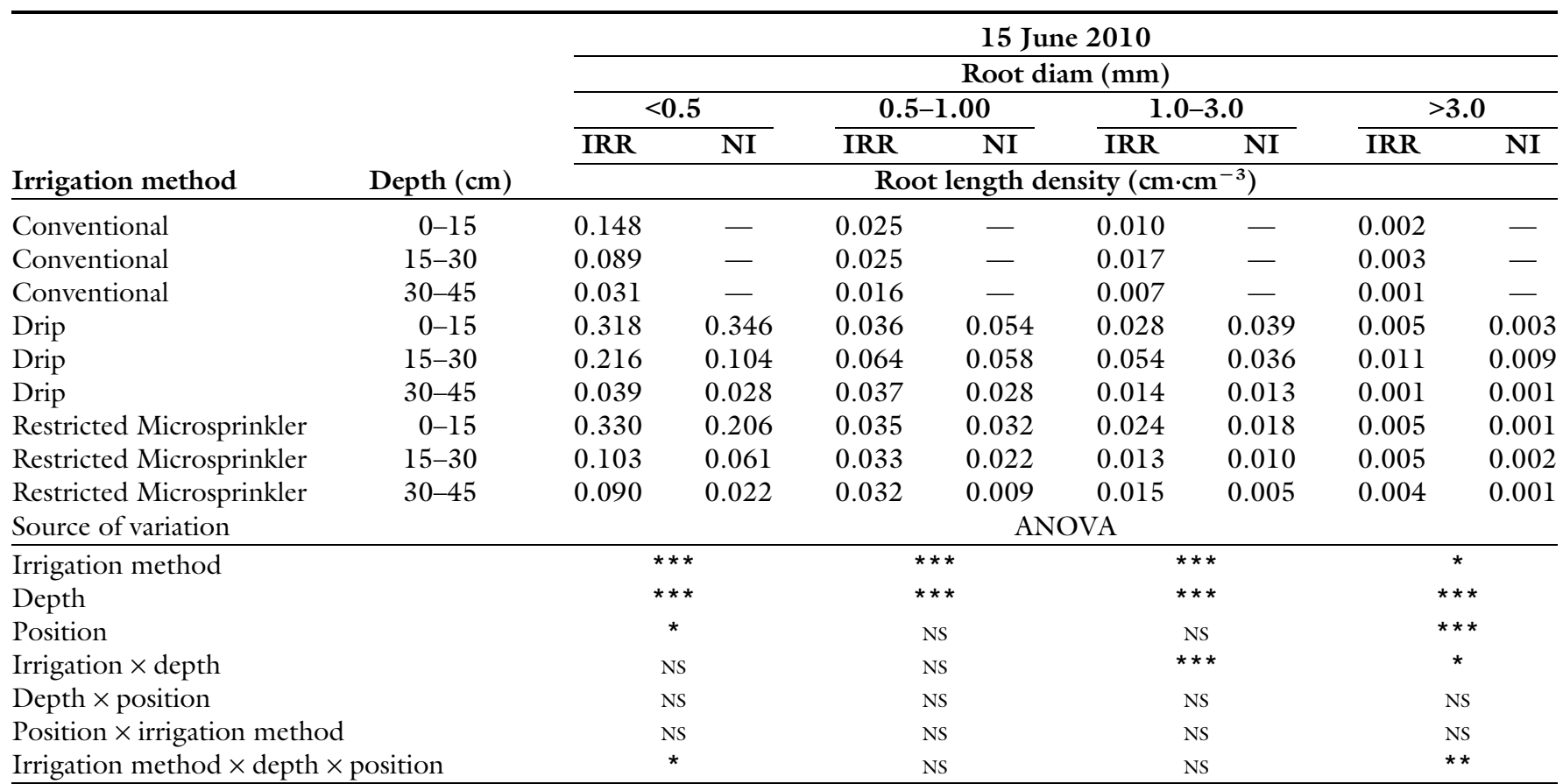

${ }^{\mathrm{z}}$ Conventional $=\mathrm{A}$ microsprinkler irrigation system irrigated with selected allowable soil water depletion between irrigations but fertigated monthly with full-circle microsprinkler; Drip = Drip irrigation system irrigated and fertigated daily with drip emitters in short pulses; Restricted Microsprinkler $=$ A modified microsprinkler irrigation system irrigated daily and fertigated weekly with 1 -m-wide and $3-\mathrm{m}$-long wetting pattern microsprinkler; $1 \mathrm{~m}=3.2808 \mathrm{ft}$.

${ }^{y} 1 \mathrm{~cm}=0.3937$ inch, $1 \mathrm{~mm}=0.0394 \mathrm{inch}, 1 \mathrm{~cm} \cdot \mathrm{cm}^{-3}=6.4516 \mathrm{inch} / \mathrm{inch}^{3}$.

${ }^{x} \mathrm{IRR}=$ irrigated zone, $\mathrm{NI}=$ nonirrigated zone.

"For conventional practices, all the sampled positions were irrigated.

NS $=$ Nonsignificant at $P<0.05 ;{ }^{*},{ }^{* *},{ }^{* *}$ Significant at $P<0.05, P<0.01$, and $P<0.001$, respectively.

\section{Results and discussion}

Comparison OF ROOT DENSITIES BY SITE. At the SS, root density increased with depth in both irrigated and nonirrigated zones across the 2 years. About $50 \%$ to $70 \%$ of the fibrous roots $(<0.5 \mathrm{~mm})$ in the irrigated zone were concentrated in the top 0 - to $15-\mathrm{cm}$ soil depth with the remaining fibrous roots in the $15-$ to $30-\mathrm{cm}$ soil depth in all treatments (Table 2; Figs. $3-5)$. However, $51 \%$ to $92 \%$ of the larger roots $(>0.5 \mathrm{~mm}$ diameter $)$ in the irrigated zone were concentrated in 15- to 30-cm soil depth. In 2009, nearly all the fibrous roots $(<0.5 \mathrm{~mm})$ in the nonirrigated zone were found in the top 0 - to $15-\mathrm{cm}$ layer probably because of the rains in summer that provided adequate moisture in the top layer. In $2010,55 \%$ to $72 \%$ of 

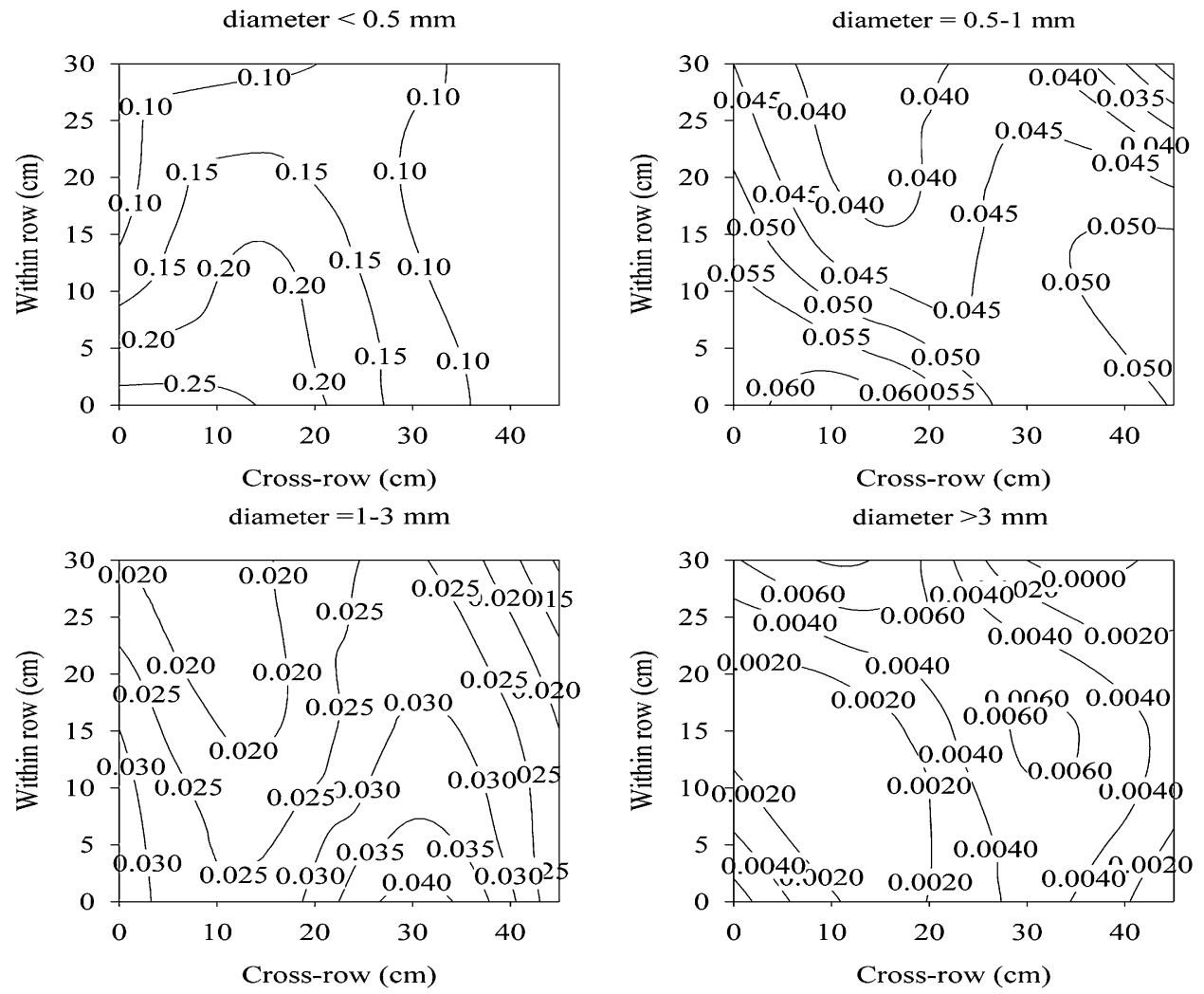

Fig. 3. Lateral root length density distribution of $<0.5-\mathrm{mm}^{-}, 0.5-$ to $1-\mathrm{mm}-, 1$ - to $3-\mathrm{mm}-$, and $>3$-mm-diameter roots of 'Hamlin' orange on 'Swingle' rootstock at the Spodosol site in June 2009 using conventional microsprinkler irrigation system irrigated with selected allowable soil water depletion between irrigations but fertigated monthly with full-circle microsprinkler (Conventional) at the Spodosol site in 2009 in the 0 - to $30-\mathrm{cm}$ soil depth layer. All contour units are $\mathrm{cm} \cdot \mathrm{cm}^{-3} ; 1 \mathrm{~mm}=0.0394$ inch, $1 \mathrm{~cm}=0.3937 \mathrm{inch}, 1 \mathrm{~cm} \cdot \mathrm{cm}^{-3}=6.4516 \mathrm{inch} / \mathrm{inch}^{3}$.

fibrous roots concentrated in the top layer (0- to $15-\mathrm{cm}$ soil depth), while larger roots $(0.5$ tol $.0 \mathrm{~mm}$ diameter $)$ were distributed evenly in the 0 - to $15-\mathrm{cm}(26 \%$ to $39 \%), 15-$ to $30-\mathrm{cm}$ (20\% to $47 \%$ ), and 30 - to $45-\mathrm{cm}$ (14\% to $32 \%$ ) soil depths (Table 3 ). Roots with diameters between 1 and $3 \mathrm{~mm}$ were concentrated in the $15-$ to $30-\mathrm{cm}$ soil depth for Conventional and Drip and in the 0 - to $15-\mathrm{cm}$ soil depth for Restricted Microsprinkler in both the irrigated and nonirrigated zones. Woody roots $(>3 \mathrm{~mm})$ contributed $<3 \%$ of total RLD in both years. These results showed greater root densities for Drip and Restricted Microsprinkler than those reported by Morgan et al. (2007) on 2- to 5-year-old 'Hamlin' and 'Valencia' orange trees because trees in that study received infrequent irrigation and fertilization via conventional practice irrigated by full circle pattern emitters with a 4.5-m diameter.

In $2009,46 \%$ to $82 \%$ of the fibrous and small roots $(<1 \mathrm{~mm}$ diameter) were concentrated in the top
0- to $15-\mathrm{cm}$ soil depth for the Drip and Restricted Microsprinkler irrigation systems, while only $34 \%$ to $41 \%$ of such roots were found at this layer in the Conventional treatment $(P \leq$ $0.001)$ at ES. As at SS, 1- to 3-mmdiameter roots were concentrated in the 15 - to $30-\mathrm{cm}$ layer $(60 \%$ to $77 \%)$ in all irrigation methods. In Summer 2010 , the trees had increased in size and developed dense fibrous roots $(<0.5 \mathrm{~mm}$ diameter $)$ with $61 \%$ to $85 \%$ of such roots found in the 0 - to $15-\mathrm{cm}$ soil layer and the rest in the 15to $30-\mathrm{cm}$ soil depth. About $60 \%$ to $80 \%$ of the larger root sizes $(>0.5 \mathrm{~mm})$ were found in $15-$ to $30-\mathrm{cm}$ soil depth in the irrigated and nonirrigated zones. Other researchers (Bassoi et al., 2003; Nappi et al., 1985) also reported similar results. The greater fibrous RLD in the ES compared with SS confirms that HLB damages fibrous roots on young trees (actually even before aboveground symptoms are apparent in 3- to 4-year-old trees) in agreement with Graham et al. (2013).
ROOT DISTRIBUTION PATTERNS OF DRIP- AND MICROSPRINKLERIRRIGATED TREES. Overall, fibrous roots accounted for $\geq 80 \%$ of the RLD at both 0 - to $15-$ and $15-$ to $30-\mathrm{cm}$ depths, while woody roots $(>3 \mathrm{~mm})$ contributed $<3 \%$ of the total RLD. Root samples collected at SS in June 2009 showed that lateral RLD distribution for the Conventional treatment decreased $(P \leq 0.001) 5$-fold from near the tree (within $15 \mathrm{~cm}$ ) to $45 \mathrm{~cm}$ away from the tree row (Figs. $3-5$ ). About $64 \%$ to $82 \%$ of the fibrous roots were concentrated in the irrigated zones of Drip and Restricted Microsprinkler and $18 \%$ to $36 \%$ were found in the nonirrigated zones. Roots in the $15-$ to $30-\mathrm{cm}$ depth in the nonirrigated zones close to the dripper or the irrigated zone of Restricted Microsprinkler had greater RLD than the irrigated zones of the Conventional irrigation, probably due to the high Florida summer rainfall.

In the second year (2010), fibrous roots samples collected at SS contributed more than $77 \%$ of RLD, 

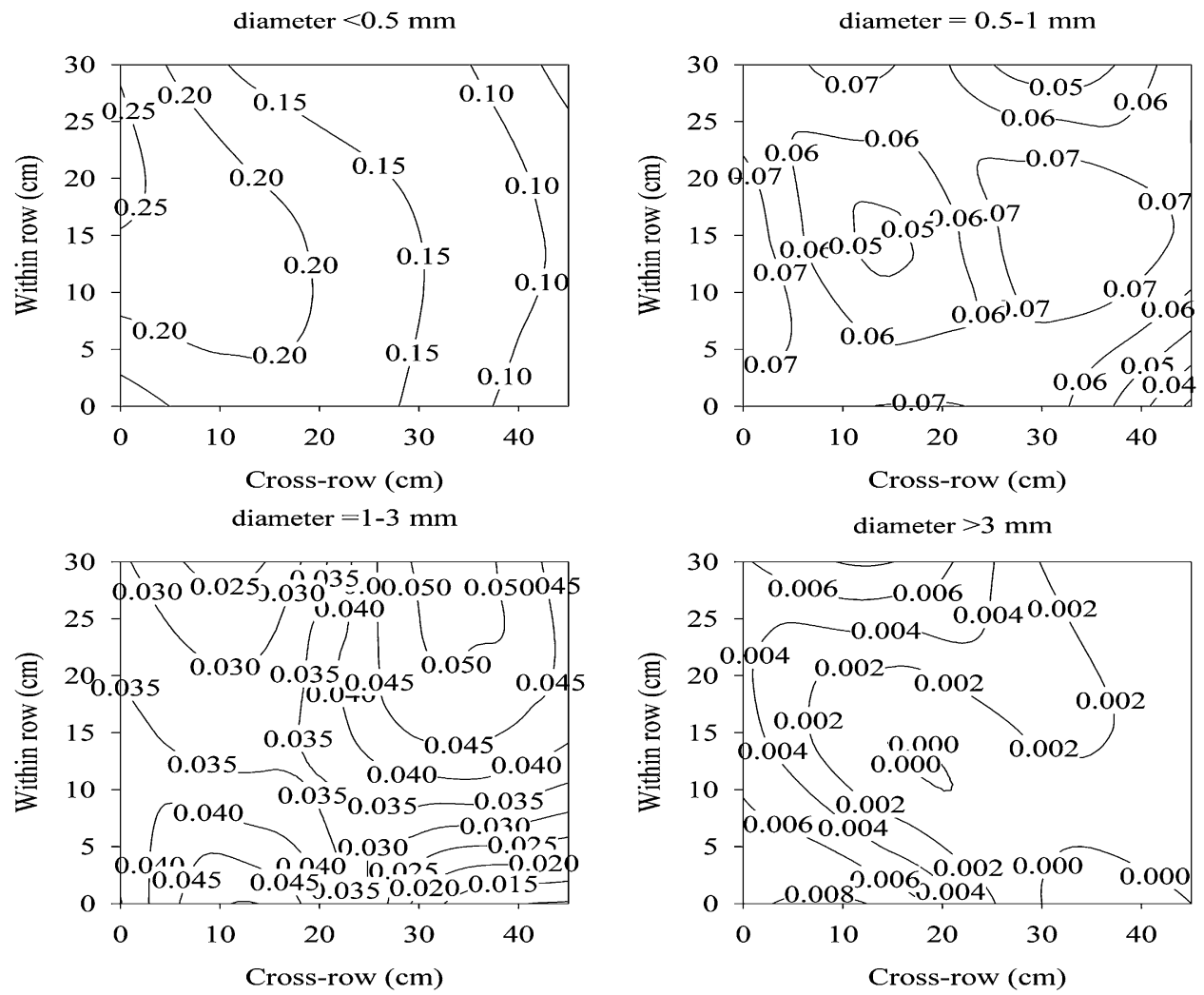

Fig. 4. Lateral root length density distribution of $<0.5-\mathrm{mm}-, 0.5$ - to $1-\mathrm{mm}-, 1$ - to 3 -mm-, and $>3$-mm-diameter roots of 'Hamlin' orange on 'Swingle' rootstock at the Spodosol site in June 2009 using drip irrigation system irrigated and fertigated daily with drip emitters in short pulses (Drip) in the 0 - to $30-\mathrm{cm}$ soil depth layer. All contour units are $\mathrm{cm} \cdot \mathrm{cm}^{-3}$; $1 \mathrm{~mm}=0.0394$ inch, $1 \mathrm{~cm}=0.3937 \mathrm{inch}, 1 \mathrm{~cm} \cdot \mathrm{cm}^{-3}=6.4516 \mathrm{inch} /$ inch $^{3}$.

while woody roots $(>3 \mathrm{~mm})$ accounted for less than $2 \%$ of total RLD. The results showed that $\approx 49 \%, 36 \%$, and $15 \%$ of roots were distributed in the 0- to 15-, 15- to 30-, and 30- to $45-\mathrm{cm}$ soil depths, respectively, for Conventional irrigation system. The RLD distributions were significantly greater in irrigated zones of Restricted Microsprinkler and Drip than those in the Conventional irrigation systems across the 2 years at SS (Table 2). Positions below the dripper or in the irrigated zone of Restricted Microsprinkler showed $53 \%$ to $81 \%$ greater RLD $(<0.5 \mathrm{~mm}$ diameter $)$ than that in nonirrigated zones $(P \leq 0.001)$ at 0 - to $15-$ and $15-$ to $30-\mathrm{cm}$ soil depths in 2009 and 2010. The RLD $(<0.5 \mathrm{~mm}$ diameter $)$ in 0 - to $15-\mathrm{cm}$ depth for Drip and Restricted Microsprinkler irrigation were 3 - to 4 -fold (nonirrigated zone) and 4- to 7 -fold (irrigated zone) greater than that for Conventional irrigation. Zhang et al. (1996, 1998) also reported that RLD of fibrous roots was significantly greater near the drip emitter and at 0 - to $15-\mathrm{cm}$ depth soil. At the 15- to 30-cm soil depth, RLD was up to two times greater in the irrigated zone of Drip-Swingle and Drip-C35 than that of the Conventional irrigated trees. However, RLD for larger roots (>0.5 mm diameter) for Drip and Restricted Microsprinkler irrigation showed similar distribution patterns between irrigated and nonirrigated zones in 2009 but greater density in the latter in $2010(P \leq 0.001)$. At ES, fibrous roots $(<0.5 \mathrm{~mm})$ accounted for $>87 \%$ and $>64 \%$ of the total RLD at 0 - to $15-$ and $15-$ to $30-\mathrm{cm}$ soil depth, respectively, across all irrigation methods. The distribution of woody roots ( $>3 \mathrm{~mm}$ diameter) was $<2 \%$. Overall, RLD found at ES was greater for drip- than microsprinklerirrigated citrus, in accord with results from grapevines (Bassoi et al., 2003; Stevens and Douglas, 1994).

COMPARISON OF ROOT DENSITIES FOR DRIP IRRIGATION. Fibrous root densities at 0 - to 15 - and 15- to 30-cm soil depths for Drip-Swingle and Drip-C35 at ES were up to 4-fold greater $(P \leq 0.001)$ than the RLD for Drip at SS in the irrigated and nonirrigated zones, respectively. Lower fibrous RLD at the SS compared with RLD at ES was probably due to interaction of HLB that infected the grove at the SS. Citrus greeninginfected trees were found to have $30 \%$ to $37 \%$ less fibrous roots compared with nonsymptomatic trees (Graham et al., 2013). Tree roots at the SS may also be limited by poor aeration and the presence of an impervious hard pan within $1 \mathrm{~m}$ from the soil surface, which impairs drainage and impedes further root proliferation.

The RLD of larger roots $(0.5$ to $3 \mathrm{~mm}$ diameter) were similar between the two sites at 0 - to $15-\mathrm{cm}$ soil depth since the trees were less than 5 years old. Because of their young age, woody roots at ES were nonexistent or very few. For example, no woody roots were found in irrigated and nonirrigated zones of Drip-Swingle (0- to $15-\mathrm{cm}$ soil depth) and in the nonirrigated zone at 0 - to 15 - and 15 to $30-\mathrm{cm}$ soil depths for Drip-C35. The drip-irrigated treatments showed high RLD of about $1.0 \mathrm{~cm} \cdot \mathrm{cm}^{-3}$ in the irrigated zone that decreased to 

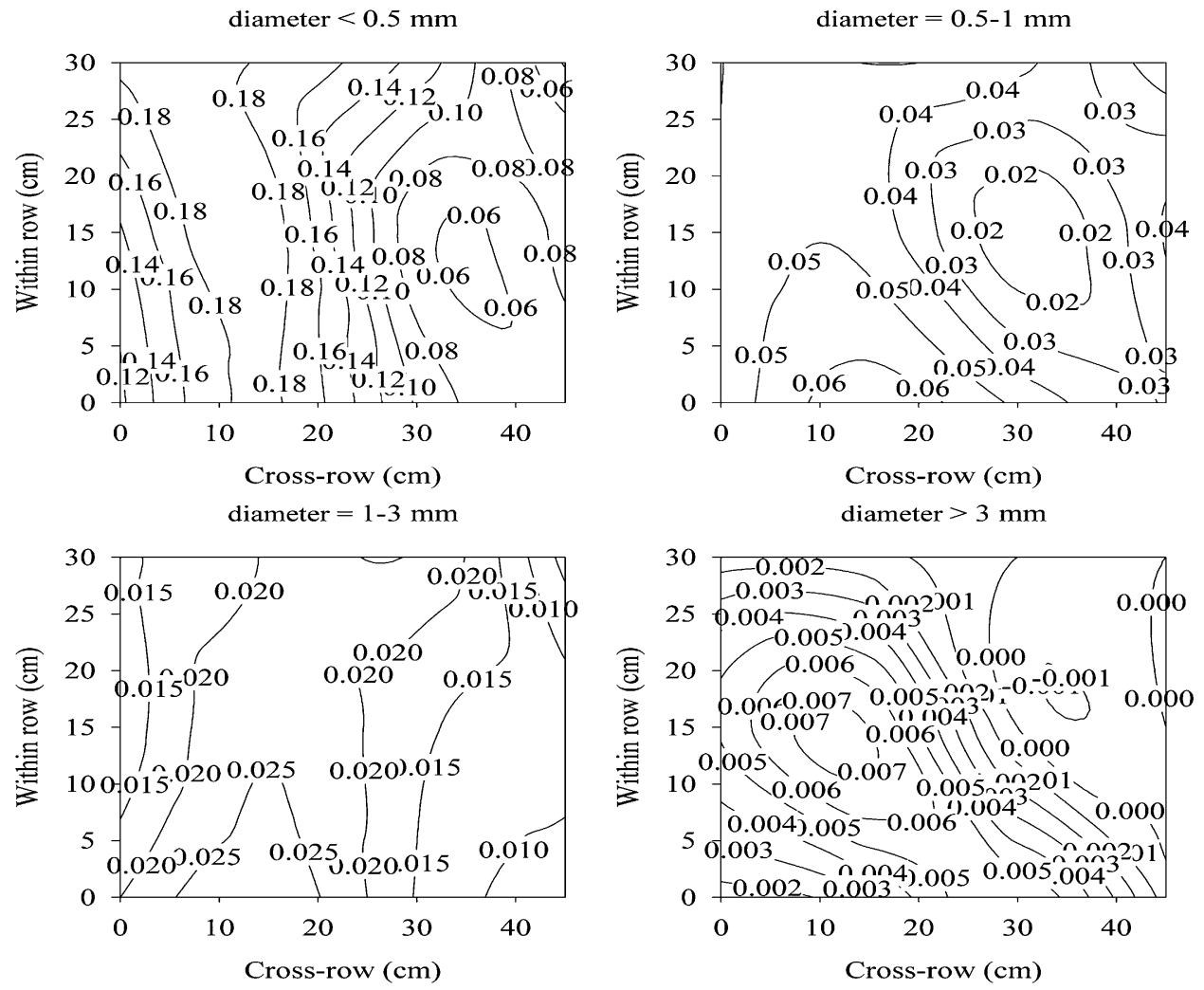

Fig. 5. Lateral root length density distribution of $<0.5-\mathrm{mm}-, 0.5-$ to $1-\mathrm{mm}-$, l- to 3-mm-, and $>3$-mm-diameter roots of 'Hamlin' orange on 'Swingle' rootstock at the Spodosol site in June 2009 using a modified microsprinkler irrigation system irrigated daily and fertigated weekly with a $1-\mathrm{m}$-wide and 3-m-long wetting pattern microsprinkler (Restricted Microsprinkler) in the 0 - to $30-\mathrm{cm}$ soil depth layer. All contour units are $\mathrm{cm} \cdot \mathrm{cm}^{-3} ; 1 \mathrm{~mm}=0.0394 \mathrm{inch}, 1 \mathrm{~m}=3.2808 \mathrm{ft}, 1 \mathrm{~cm}=0.3937 \mathrm{inch}$, $1 \mathrm{~cm} \cdot \mathrm{cm}^{-3}=6.4516 \mathrm{inch} / \mathrm{inch}^{3}$.

$0.20 \mathrm{~cm} \cdot \mathrm{cm}^{-3}$ in the nonirrigated zone at ES. The high RLDs in the nonirrigated zones for the Drip and Restricted Microsprinkler fertigation methods were not expected. We ascribe the presence of roots in the nonirrigated zone to the high rainfall in Florida (Fig. 2), which increased the amount of available water including the nonirrigated zone thus promoting root growth and development. For example, there were unusually high rains in Dec. 2009, Jan. 2010, Feb. 2010, Mar. 2010, and Apr. 2010 ranging from $65 \%$ to $235 \%$ at SS and $43 \%$ to $278 \%$ at ES greater than 10 year average of these months (calculated from 1 Jan. 2000 to 31 Dec. 2010 ) that might have supplied water in the dry months in the nonirrigated zones. Obreza and Pitts (2002) also observed similar phenomena on RLD distribution between the irrigated and nonirrigated zones of southwestern Florida. The results show RLD $<1.3 \mathrm{~cm} \cdot \mathrm{cm}^{-3}$, consistent with findings of other researchers in citrus (Mattos et al., 2003), apple [Malus domestica (De Silva et al.,
1999)], and somewhat lower than the RLD reported by Coleman (2007) in other woody species.

LATERAL SOIL MOISTURE DISTRIBUTION. Results at SS showed higher water contents in the 15- to $30-\mathrm{cm}$ soil depth layer in 2009 and moisture contents in the decreasing order of $30-45 \mathrm{~cm}>15-30 \mathrm{~cm}>$ 0-15 cm in 2010 (Table 4; Fig. 6). The significantly lower soil moisture contents point to the decreasing RLD with depth suggesting that most of the water in the upper soil layers were depleted by root uptake, surface evaporation, or drainage. Our own results (Kadyampakeni, 2012) and those of Zhang et al. (1996) showed that tree uptake should be greater in the 0 - to $15-\mathrm{cm}$ soil layer than lower horizons due to higher root density in the range of $55 \%$ to $67 \%$ on length basis and $70 \%$ to $75 \%$ on weight basis in the top $15 \mathrm{~cm}$. Davenport et al. (2008) also observed that soil moisture distribution for drip-irrigated vineyards was adequate in the 0 - to $45-\mathrm{cm}$ depth and within 20 - to $40-\mathrm{cm}$ radius, either diagonal or perpendicular to the drip line. Our observations are also in agreement with Goldberg et al. (1971) who found that soil moisture resulting from drip irrigation was two-dimensional, with moisture contents high along and beneath the row and decreasing laterally. Thus, the effect of shorter irrigation intervals, as was the case with Drip and Restricted Microsprinkler, with proportionally smaller amounts of water applied in a single irrigation, is to reduce the variations in moisture content in the root zone and establish a continuously higher moisture regime. The irrigated and nonirrigated zones were similar in both years owing to high rainfall at SS totaling 518 and $218 \mathrm{~mm}$ in May/June of 2009 and 2010 , respectively. The rains in May/June 2009 were $49 \%$ greater than a 10-year average for these months, while the rains in May/June 2010 were very similar to the 10-year average. Thus, even the nonirrigated zones of all treatments remained wet. Obreza and Pitts (2002) also found that availability of moisture in the root zone may promote root development even 


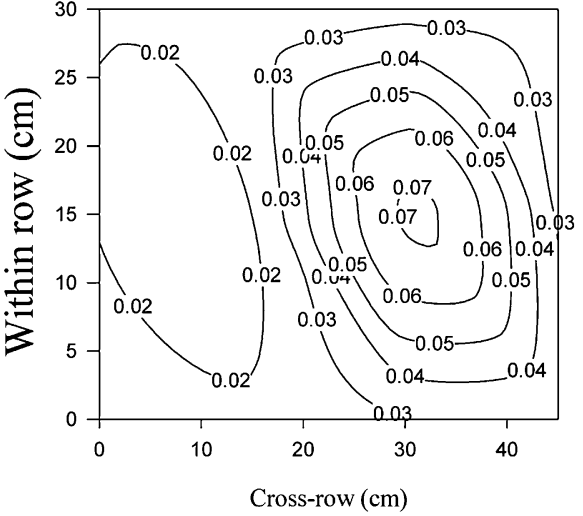

Restricted microsprinkler (June 2010)

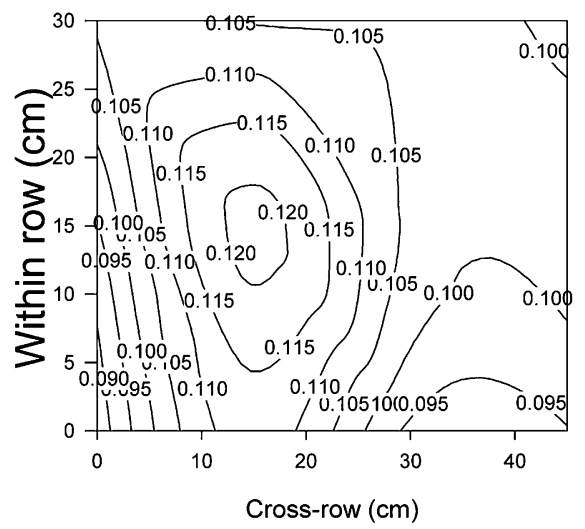

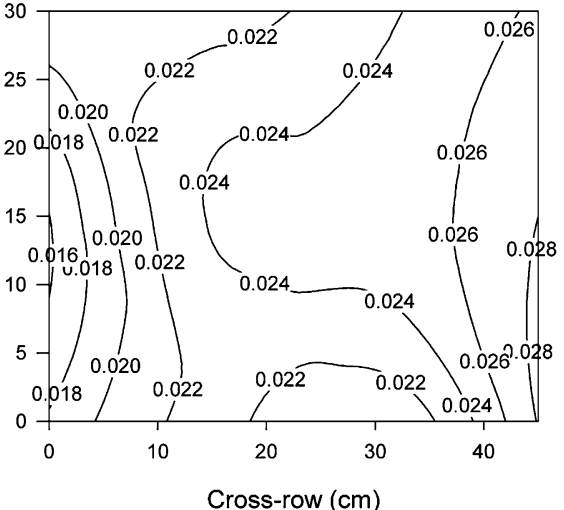

Drip (June 2010)

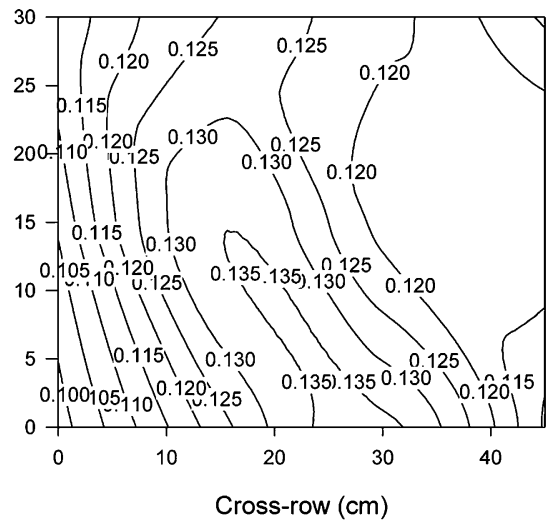

Cross-row $(\mathrm{cm})$

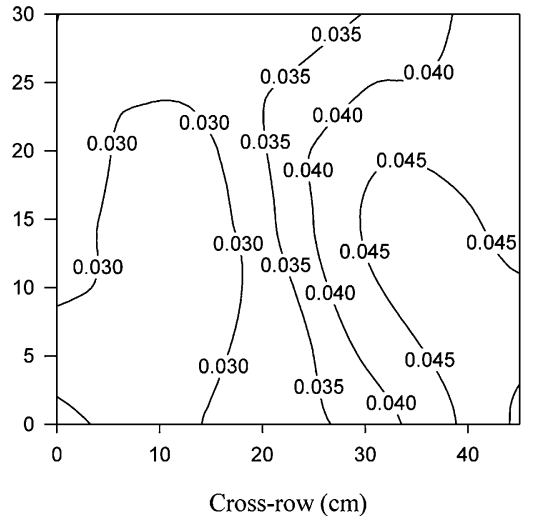

Conventional (June 2010)

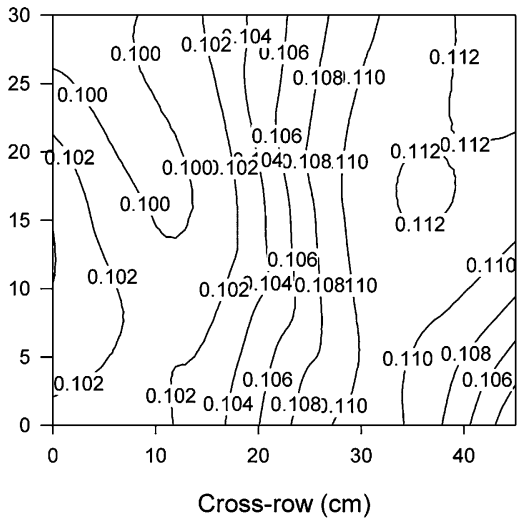

Soil moisture $\left(\mathrm{cm}^{3} \mathrm{~cm}^{-3}\right)$

Fig. 6. Lateral soil moisture distribution at the Spodosol Site in June 2009 (0- to 30-cm depth) and June 2010 (0- to $45-\mathrm{cm}$ depth) using drip irrigation system irrigated and fertigated daily with drip emitters in short pulses (Drip), a modified microsprinkler irrigation system irrigated daily and fertigated weekly with a $\mathbf{1}-\mathbf{m}$-wide and 3 -m-long wetting pattern microsprinkler (Restricted Microsprinkler), and conventional microsprinkler irrigation system irrigated with selected allowable soil water depletion between irrigations but fertigated monthly with full-circle microsprinkler (Conventional). All trees were 'Hamlin' orange on 'Swingle' rootstock. All contour units are $\mathrm{cm}^{3} \mathrm{~cm}^{-3} ; 1 \mathrm{~cm}=0.3937 \mathrm{inch} ; 1 \mathrm{~m}=3.2808 \mathrm{ft}, 1 \mathrm{~cm}^{3}=0.0610$ inch $^{3}$.

in the nonirrigated zones. The moisture contents in 2009 were collected just within $30 \%$ to $50 \%$ soil moisture depletion, while the soil samples in 2010 were determined after an irrigation event and were all above field capacity. Additionally in 2010, another drip line was placed on each side of the tree at Immokalee due to the increase in tree size resulting in eight drippers on either side of the tree. The sampling was limited to one quadrant assuming uniform root distribution on the within-row bed in the northwest or northeast of the tree sampled.

In stark contrast to observations at SS, the soil moisture contents in samples collected at ES in Dec. 2009 and June 2010 decreased with depth in all treatments with soil moisture contents well above field capacity at both sampling times (Fig. 7, Table 5 ). Also, there were no differences between irrigated and nonirrigated zones owing to the $89 \mathrm{~mm}$ of rain in Dec. 2009 (which was $175 \%$ greater than the 10-year average rainfall for the month of December) and $322 \mathrm{~mm}$ in June and July 2010 (which represented $46 \%$ less rainfall than a 10 -year average for the months of June and July), which might have accounted for high soil moisture availability in the nonirrigated zone. Also, low evapotranspiration coupled with low temperatures in December at ES suggest minimal losses due to evaporation in the 0 - to $15-\mathrm{cm}$ soil layer. The significantly higher root density in the irrigated than nonirrigated zones suggest that water uptake might have been greater in the former than the latter because root water uptake is intrinsically related to root density (Tinker and Nye, 2000). The fact that water contents were mostly greater than field capacity moisture content suggests that more water was available for uptake. Miller (1967) pointed out that the actual amount of plant available moisture in the active soil layer can be considerably greater than the range between standard field capacity and wilting point. Furthermore, Goldberg et al. (1971) noted that if a part of the drainable water remains in the root zone for a time sufficient for its absorption by the roots, it will add to the actual amount of available water. Drip irrigation in small pulses or daily applications with restricted microsprinklers provide for tree consumptive 
Table 3. Means and analysis of variance (ANOVA) for citrus root length density distribution as a function of irrigation method (Conventional, Drip, and Restricted Microsprinkler irrigation systems), soil depth, and distance from the tree at the Entisol site on 22 Dec. 2009 and 28 July 2010 in irrigated and nonirrigated zones at 0- to $15-\mathrm{cm}$ and $15-$ to $30-\mathrm{cm}$ soil depths.

\begin{tabular}{|c|c|c|c|c|c|c|c|c|c|}
\hline \multirow[b]{5}{*}{ Irrigation method $^{\mathrm{z}}$} & \multirow[b]{5}{*}{ Depth $(\mathrm{cm})^{\mathrm{y}}$} & \multicolumn{8}{|c|}{$\operatorname{Root} \operatorname{diam}(\mathrm{mm})^{\mathrm{y}}$} \\
\hline & & \multicolumn{2}{|c|}{$<0.5$} & \multicolumn{2}{|c|}{$0.5-1.0$} & \multicolumn{2}{|c|}{$1.0-3.0$} & \multicolumn{2}{|c|}{$>3.0$} \\
\hline & & \multicolumn{8}{|c|}{22 Dec. 2009} \\
\hline & & IRR $^{x}$ & $\mathrm{NI}^{\mathbf{x}}$ & IRR & NI & IRR & NI & IRR & NI \\
\hline & & \multicolumn{8}{|c|}{ Root length density $\left(\mathrm{cm} \cdot \mathrm{cm}^{-3}\right)^{\mathrm{y}}$} \\
\hline Drip-Swingle & $0-15$ & 0.777 & 0.404 & 0.041 & 0.072 & 0.029 & 0.017 & 0.000 & 0.000 \\
\hline Drip-Swingle & $15-30$ & 0.407 & 0.261 & 0.048 & 0.061 & 0.044 & 0.044 & 0.003 & 0.003 \\
\hline Restricted Microsprinkler & $0-15$ & 0.428 & 0.351 & 0.079 & 0.054 & 0.015 & 0.012 & 0.000 & 0.004 \\
\hline Restricted Microsprinkler & $15-30$ & 0.124 & 0.109 & 0.037 & 0.029 & 0.040 & 0.013 & 0.000 & 0.000 \\
\hline Drip-C35 & $0-15$ & 0.811 & 0.347 & 0.044 & 0.060 & 0.003 & 0.031 & 0.002 & 0.000 \\
\hline Drip-C35 & $15-30$ & 0.323 & 0.077 & 0.019 & 0.008 & 0.010 & 0.005 & 0.002 & 0.000 \\
\hline \multicolumn{2}{|l|}{ Source of variation } & \multicolumn{8}{|c|}{ ANOVA } \\
\hline Depth $\times$ position & & \multicolumn{2}{|c|}{ NS } & \multicolumn{2}{|c|}{ NS } & \multicolumn{2}{|c|}{ NS } & \multicolumn{2}{|c|}{ NS } \\
\hline Position $\times$ irrigation metho & & \multicolumn{2}{|c|}{ NS } & \multicolumn{2}{|c|}{ NS } & \multicolumn{2}{|c|}{ NS } & & \\
\hline Irrigation method $\times$ depth & osition & & & & & & & & \\
\hline
\end{tabular}

\begin{tabular}{|c|c|c|c|c|c|c|c|c|c|}
\hline \multirow[b]{5}{*}{ Irrigation method } & \multirow[b]{5}{*}{ Depth $(\mathrm{cm})$} & \multicolumn{8}{|c|}{28 July 2010} \\
\hline & & \multicolumn{8}{|c|}{ Root diam (mm) } \\
\hline & & \multicolumn{2}{|c|}{$<0.5$} & \multicolumn{2}{|c|}{$0.5-1.0$} & \multicolumn{2}{|c|}{$1.0-3.0$} & \multicolumn{2}{|c|}{$>3.0$} \\
\hline & & IRR & NI & IRR & NI & IRR & NI & IRR & NI \\
\hline & & \multicolumn{8}{|c|}{ Root length density $\left(\mathrm{cm} \cdot \mathrm{cm}^{-3}\right)$} \\
\hline Drip-Swingle & $0-15$ & 1.172 & 0.885 & 0.033 & 0.036 & 0.026 & 0.019 & 0.010 & 0.000 \\
\hline Drip-Swingle & $15-30$ & 0.543 & 0.185 & 0.030 & 0.027 & 0.040 & 0.016 & 0.007 & 0.001 \\
\hline Restricted Microsprinkler & $0-15$ & 0.564 & 0.487 & 0.026 & 0.038 & 0.023 & 0.019 & 0.004 & 0.002 \\
\hline Restricted Microsprinkler & $15-30$ & 0.218 & 0.083 & 0.022 & 0.027 & 0.018 & 0.029 & 0.006 & 0.000 \\
\hline Drip-C35 & $0-15$ & 1.195 & 0.582 & 0.008 & 0.017 & 0.010 & 0.017 & 0.004 & 0.005 \\
\hline Drip-C35 & $15-30$ & 0.293 & 0.165 & 0.012 & 0.017 & 0.008 & 0.016 & 0.000 & 0.001 \\
\hline \multicolumn{2}{|l|}{ Source of variation } & \multicolumn{8}{|c|}{ ANOVA } \\
\hline Depth $\times$ & & & & & & & & & \\
\hline Position $\times$ irrigation $n$ & & & & & & & & & \\
\hline Irrigation method $\times$ depth & osition & & & & & & & & \\
\hline
\end{tabular}

${ }^{2}$ Drip-Swingle $=$ Drip irrigation system installed for 'Hamlin' orange on 'Swingle' rootstock irrigated and fertigated daily with drip emitters in short pulses; Conventional = Conventional microsprinkler irrigation system used by Florida citrus growers irrigated with selected allowable soil water depletion between irrigations but fertilized with granular fertilizer four to six times per year ('Hamlin' orange/'Swingle'); Restricted Microsprinkler = A microsprinkler irrigation system irrigated daily and fertigated weekly with a 1 -m-wide and 3-m-long wetting a pattern microsprinkler ('Hamlin' orange/'Swingle'); Drip-C35 = Drip irrigation system installed for 'Hamlin' orange on 'C35' rootstock irrigated and fertigated daily with drip emitters in short pulses; $1 \mathrm{~m}=3.2808 \mathrm{ft}$.

${ }^{\mathrm{y}} 1 \mathrm{~cm}=0.3937$ inch, $1 \mathrm{~mm}=0.0394 \mathrm{inch}, 1 \mathrm{~cm} \cdot \mathrm{cm}^{-3}=6.4516 \mathrm{inch} / \mathrm{inch}^{3}$

${ }^{x} \mathrm{IRR}=$ irrigated zone, $\mathrm{NI}=$ nonirrigated zone.

wFor conventional practices, all the sampled positions were irrigated.

NS $=$ Nonsignificant at $P<0.05 ;{ }^{*},{ }^{*},{ }^{* *}$ Significant at $P<0.05, P<0.01$, and $P<0.001$, respectively.

water use at a higher level, (i.e., more efficacious) than weekly irrigation by conventional means. Water distribution in the irrigated zones was within 10 to $30 \mathrm{~cm}$ from the drippers as reported by other researchers (Badr and Abuarab, 2013; Davenport et al., 2008).

\section{Conclusion}

This study demonstrated that RLDs in the irrigated zones were greater for intensive irrigation and fertigation managed young citrus trees compared with less intensive conventional grower practices. These results were not known before this study and could provide useful information in 
Table 4. Means and analysis of variance (ANOVA) for lateral soil moisture distribution using Conventional, Drip, and Restricted Microsprinkler irrigation systems at the Spodosol site in June 2009 and 2010 in irrigated and nonirrigated zones at 0 - to $15-\mathrm{cm}, 15-$ to $30-\mathrm{cm}$, and $30-$ to $45-\mathrm{cm}$ soil depths. All trees were 'Hamlin' orange on 'Swingle' rootstock.

\begin{tabular}{|c|c|c|c|c|c|}
\hline \multirow{3}{*}{$\begin{array}{l}\text { Irrigation } \\
\text { method }^{\mathrm{z}}\end{array}$} & \multirow[b]{3}{*}{ Depth $(\mathrm{cm})^{\mathrm{y}}$} & \multicolumn{2}{|c|}{2009} & \multicolumn{2}{|c|}{2010} \\
\hline & & Irrigated & Nonirrigated & Irrigated & Nonirrigated \\
\hline & & \multicolumn{4}{|c|}{ Soil moisture content $\left[\text { mean } \pm S D\left(\mathrm{~cm}^{3} \cdot \mathrm{cm}^{-3}\right)\right]^{\mathrm{x}}$} \\
\hline Conv. & $15-30$ & $0.037 \pm 0.017$ & - & $0.106 \pm 0.061$ & - \\
\hline Conv. & $30-45$ & - & - & $0.117 \pm 0.069$ & - \\
\hline Drip & $0-15$ & $0.023 \pm 0.012$ & $0.015 \pm 0.014$ & $0.106 \pm 0.051$ & $0.088 \pm 0.047$ \\
\hline $\mathrm{RM}$ & $0-15$ & $0.018 \pm 0.013$ & $0.018 \pm 0.008$ & $0.096 \pm 0.065$ & $0.076 \pm 0.041$ \\
\hline $\mathrm{RM}$ & $15-30$ & $0.028 \pm 0.015$ & $0.046 \pm 0.031$ & $0.102 \pm 0.048$ & $0.105 \pm 0.046$ \\
\hline $\mathrm{RM}$ & $30-45$ & - & - & $0.135 \pm 0.049$ & $0.130 \pm 0.051$ \\
\hline \multicolumn{2}{|c|}{ Source of variation } & \multicolumn{4}{|c|}{ ANOVA } \\
\hline \multicolumn{2}{|c|}{ Irrigation method } & \multicolumn{2}{|c|}{$* * *$} & \multicolumn{2}{|c|}{$* * *$} \\
\hline
\end{tabular}

${ }^{\mathrm{z} C o n v} .=$ Conventional microsprinkler practice, Drip $=$ Drip irrigation system, $\mathrm{RM}=$ Restricted Microsprinkler irrigation system.

${ }^{y} 1 \mathrm{~cm}=0.3937$ inch.

'Soil moisture expressed as volumetric moisture content; $1 \mathrm{~cm}^{3}=0.0610 \mathrm{inch}^{3}$.

wot applicable.

NS $=$ Nonsignificant at $P<0.05 ;{ }^{*},{ }^{*}{ }^{*}$ Significant at $P<0.05$ and $P<0.001$, respectively.
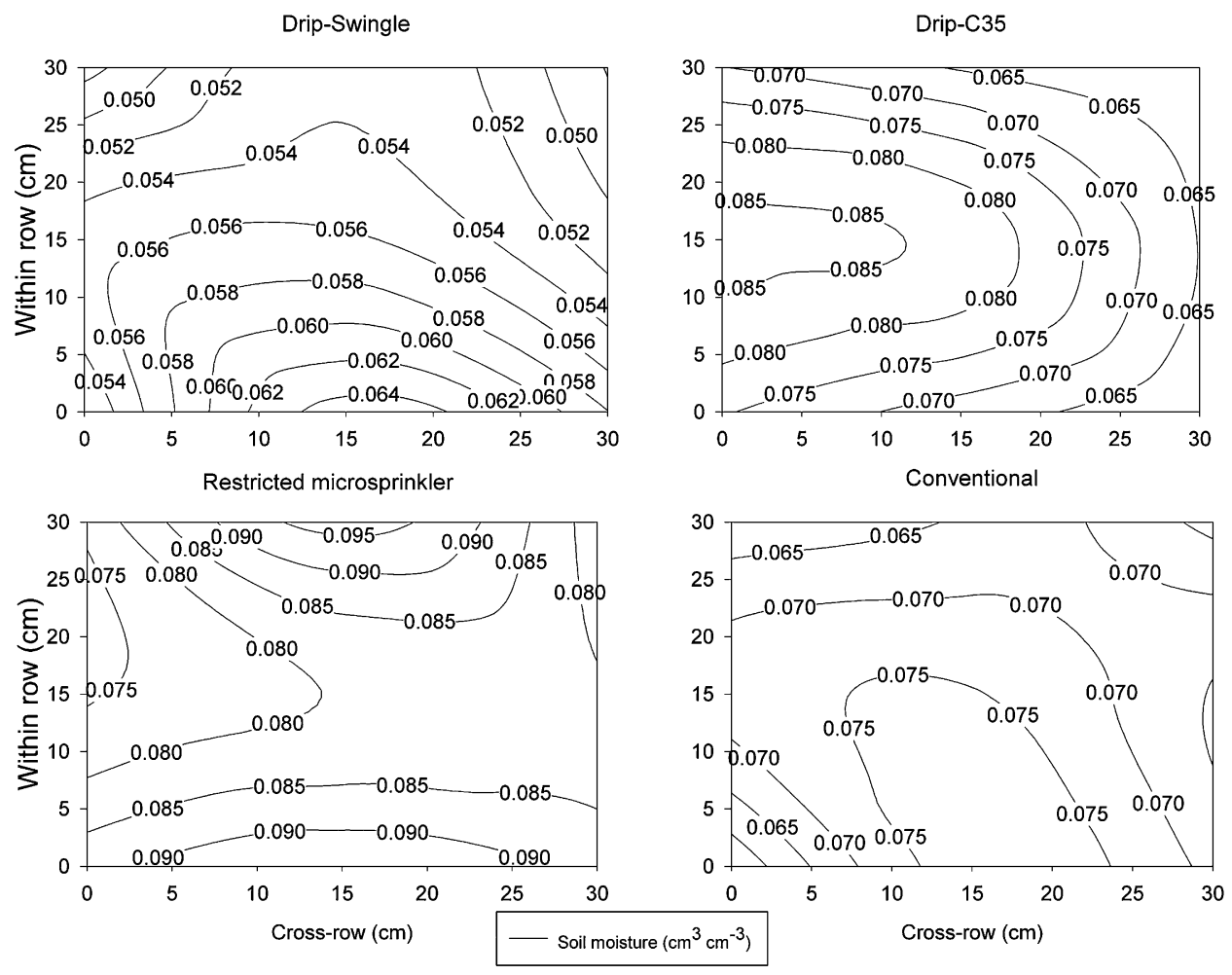

Fig. 7. Lateral soil moisture distribution at the Entisol Site in the 0 - to $30-\mathrm{cm}$ depth layer in July 2010 using drip irrigation system installed for 'Hamlin' orange on 'Swingle' rootstock irrigated and fertigated daily with drip emitters in short pulses (Drip-Swingle), conventional microsprinkler irrigation system used by Florida citrus growers irrigated with selected allowable soil water depletion between irrigations but fertilized with granular fertilizer four to six times per year (Conventional), a microsprinkler irrigation system irrigated daily and fertigated weekly with a 1 -m-wide and 3-m-long wetting a pattern microsprinkler (Restricted Microsprinkler), and drip irrigation system installed for 'Hamlin' orange on 'C35' rootstock irrigated and fertigated daily with drip emitters in short pulses (Drip-C35). All contour units are $\mathrm{cm}^{3} \cdot \mathrm{cm}^{-3} ; 1 \mathrm{~cm}=0.3937$ inch; $1 \mathrm{~m}=3.2808 \mathrm{ft}, 1 \mathrm{~cm}^{3}=0.0610$ inch $^{3}$. 
Table 5. Means and analysis of variance (ANOVA) for lateral soil moisture distribution using Conventional, Drip, and Restricted Microsprinkler irrigation systems at the Entisol site in Dec. 2009 and July 2010 in irrigated and nonirrigated zones at 0- to 15- and 15 - to $30-\mathrm{cm}$ soil depths.

\begin{tabular}{|c|c|c|c|c|c|}
\hline \multirow[b]{3}{*}{ Irrigation method $^{\mathrm{z}}$} & \multirow[b]{3}{*}{ Depth $(\mathrm{cm})^{\mathrm{y}}$} & \multicolumn{2}{|c|}{2009} & \multicolumn{2}{|c|}{2010} \\
\hline & & Irrigated & Nonirrigated & Irrigated & Nonirrigated \\
\hline & & \multicolumn{4}{|c|}{ Soil moisture content $\left[\text { mean } \pm S D\left(\mathrm{~cm}^{3} \mathrm{~cm}^{-3}\right)\right]^{\mathrm{x}}$} \\
\hline Conv. & $15-30$ & $0.057 \pm 0.018$ & - & $0.057 \pm 0.019$ & - \\
\hline Drip-Swingle & $0-15$ & $0.072 \pm 0.008$ & $0.067 \pm 0.010$ & $0.057 \pm 0.029$ & $0.056 \pm 0.021$ \\
\hline Drip-Swingle & $15-30$ & $0.065 \pm 0.017$ & $0.079 \pm 0.043$ & $0.046 \pm 0.021$ & $0.054 \pm 0.021$ \\
\hline $\mathrm{RM}$ & $0-15$ & $0.088 \pm 0.012$ & $0.085 \pm 0.009$ & $0.085 \pm 0.027$ & $0.094 \pm 0.044$ \\
\hline $\mathrm{RM}$ & $15-30$ & $0.084 \pm 0.010$ & $0.082 \pm 0.012$ & $0.074 \pm 0.024$ & $0.078 \pm 0.023$ \\
\hline Source of variation & & \multicolumn{4}{|c|}{ ANOVA } \\
\hline Irrigation method & & \multicolumn{2}{|c|}{ ** } & \multicolumn{2}{|c|}{$* * *$} \\
\hline Depth & & \multicolumn{2}{|c|}{ NS } & \multicolumn{2}{|c|}{ ** } \\
\hline
\end{tabular}

${ }^{2}$ Drip-Swingle = Drip irrigation system with 'Hamlin' orange on 'Swingle' rootstock; Conv. = Conventional microsprinkler irrigation practice ('Hamlin' orange/'Swingle'); Drip-C35 = Drip irrigation system with 'Hamlin' orange on 'C35' rootstock; RM = Restricted Microsprinkler irrigation system ('Hamlin' orange/'Swingle').

${ }^{y} 1 \mathrm{~cm}=0.3937$ inch.

${ }^{x}$ Soil moisture expressed as volumetric moisture content; $1 \mathrm{~cm}^{3}=0.0610$ inch $^{3}$.

"Not applicable.

NS $=$ Nonsignificant at $P<0.05 ;{ }^{*},{ }^{*} *$ Significant at $P<0.01$ and $P<0.001$, respectively.

models for estimating water use and nutrient uptake in young citrus trees ( $<6$ years old). About $64 \%$ to $82 \%$ of the fibrous roots were concentrated in the irrigated zones of Drip and Restricted Microsprinkler and 18\% to $36 \%$ was found in the nonirrigated zones at SS. At ES, the RLD of fibrous roots $(<0.5 \mathrm{~mm}$ diameter $)$ for trees grown with intensively managed irrigation systems were 3 - to 7 -fold greater at 0 - to $15-\mathrm{cm}$ soil depth than that for conventional irrigation management. Further, higher RLD was observed in the 0 - to $15-\mathrm{cm}$ soil depth and decreased with depth for all treatments at both sites. Fibrous root densities at 0 - to $15-\mathrm{cm}$ soil depth for Drip at the ES were up to 4-fold greater than the RLD for Drip at SS in the irrigated and nonirrigated zones due to greater number of drip emitters and as a result of HLB disease pressure. Results showed significant differences in soil moisture between Drip, the Restricted Microsprinkler, and Conventional irrigation methods. Laterally, there were no differences between irrigated and nonirrigated zones even in the irrigation methods where water application was limited to positions above or near the root zone due to the heavy rains associated with the summer months in Florida. Thus, use of intensive irrigation and fertigation management should help in promoting citrus root development, water and nutrient uptake, and improved management of
HLB-infected trees without limiting tree production on Florida's Spodosols and Entisols.

\section{Literature cited}

Abrisqueta, J.M., O. Mounzer, S. Alvarez, W. Conejero, Y. Garcia-Orellana, L.M. Tapia, J. Vera, I. Abrisqueta, and M.C. Ruiz-Sanchez. 2008. Root dynamics of peach trees submitted to partial rootzone drying and continuous deficit irrigation. Agr. Water Mgt. 95:959-967.

Alva, A.K. and J.P. Syvertsen. 1991. Irrigation water salinity affects soil nutrient distribution, root density, and leaf nutrient levels of citrus under drip fertigation. J. Plant Nutr. 14:715-727.

Alva, A., S. Paramasivam, W. Graham, and T. Wheaton. 2003. Best nitrogen and irrigation management practices for citrus production in sandy soils. Water Air Soil Pollut. 143:139-154.

Alva, A.K., S. Paramasivam, T.A. Obreza, and A.W. Schumann. 2006. Nitrogen best management practice for citrus trees - I. Fruit yield, quality, and leaf nutritional status. Sci. Hort. 107:233-244.

Badr, A.E. and M.E. Abuarab. 2013. Soil moisture distribution patterns under surface and subsurface drip irrigation systems in sandy soil using neutron scattering technique. Irr. Sci. 31:317-332.

Bassoi, L.H., J.W. Hopmans, L.A.C. Jorge, C.M. Alencar, and J.A.M. Silva. 2003. Grapevine root distribution in drip and microsprinkler irrigation. Scientia Agr. 60:377-387.
Böhm, W. 1979. Method of studying root systems. Springer, New York, NY.

Carrasco, G., O. Márquez, M. Urrestarazu, and M.C. Salas. 2003. Transplants grown hydroponically are an alternative for soil. Acta Hort. 609:407-410.

Castle, W.S. 1980. Fibrous root distribution of 'Pineapple' orange trees on rough lemon rootstock at three tree spacings. J. Amer. Soc. Hort. Sci. 105:478-480.

Castle, W.S. and A.H. Krezdorn. 1975. Effect of citrus rootstocks on root distribution and leaf mineral content of 'Orlando' tangelo tree. J. Amer. Soc. Hort. Sci. 100:1-4.

Coleman, M. 2007. Spatial and temporal patterns of root distribution in developing stands of four woody crop species grown with drip irrigation and fertilization. Plant Soil 299:195-213.

Davenport, J., R. Stevens, and K. Whitley. 2008. Spatial and temporal distribution of soil moisture in drip-irrigated vineyards. HortScience 43:229-235.

Davies, B. 1974. Loss-on-ignition as an estimate of soil organic matter. Soil Sci. Soc. Amer. J. 38:150-151.

De Silva, H.N., A.J. Hall, D.S. Tustin, and P.W. Gandar. 1999. Analysis of distribution of root length density of apple trees on different dwarfing rootstocks. Ann. Bot. (Lond.) 83:335-345.

Eissenstat, D.M. 1991. On the relationship between specific root length and the rate of root proliferation: A field study using citrus rootstocks. New Phytol. 118:63-68. 
Escamilla, J.A., N.B. Comerford, and D.G. Neary. 1991. Soil core-break method to estimate pine root distribution. Soil Sci. Soc. Amer. J. 55:17221726.

Fares, A. and A.K. Alva. 2000. Evaluation of capacitance probes for optimal irrigation of citrus through soil moisture monitoring in an Entisol profile. Irr. Sci. 19:57-64.

Fares, A., A. Dogan, F. Abbas, L. Parsons, T. Obreza, and K. Morgan. 2008. Water balance components in a mature citrus orchard. Soil Sci. Soc. Amer. J. 72:578585 .

Goldberg, S., M. Rinot, and N. Karu. 1971. Effect of trickle irrigation intervals on distribution and utilization of soil moisture in a vineyard. Soil Sci. Soc. Amer. Proc. 35:127-130.

Graham, J.H., E.G. Johnson, T.R. Gottwald, and M.S. Irey. 2013. Presymptomatic fibrous root decline in citrus trees caused by Huanglongbing and potential interaction with Phytophthora spp. Plant Dis. 97:1195-1199.

Hillel, D. 1998. Environmental Soil Physics. Academic Press, San Diego, CA.

Kadyampakeni, D.M. 2012. Citrus advanced production system: Understanding water and NPK uptake and leaching in Florida Flatwoods and Ridge soils. Univ. Florida, Gainesville, Ph.D. Diss.

Kimura, K. and S. Yamasaki. 2001. Root length and diameter measurement using NIH image: Application of the lineintercept principle for diameter estimation. Plant Soil 234:37-46.

Koo, R.C.J. 1980. Results of citrus fertigation studies. Proc. Florida State Hort. Sci. 93:33-36.

Kruger, J.A., C.D. Tolmay, and K. Britz. 2000a. Effects of fertigation frequencies and irrigation systems on performance of Valencia oranges in two subtropical areas of South Africa. Proc. Intl. Soc. Citricult. IX Congr. 232-235.

Kruger, J.A., K. Britz, C.D. Tolmay, and S.F. du Plessis. 2000b. Evaluation of an open hydroponics system (OHS) for citrus in South Africa: Preliminary results.
Proc. Intl. Soc. Citricult. IX Congr. p. 239-242.

Lopez-Zamora, I., N. Falcão, N.B. Comerford, and N.F. Barros. 2002. Root isotropy and an evaluation of a method for measuring root distribution in soil trenches. For. Ecol. Mgt. 166:303-310.

Martinez-Valero, R. and C. Fernandez. 2004. Preliminary results on citrus groves under the MOHT system. Proc. Intl. Soc. Citricult. X Congr. p. 103. (abstr.).

Mattos, D. 2000. Citrus response functions to $\mathrm{N}, \mathrm{P}$, and $\mathrm{K}$ fertilization and $\mathrm{N}$ uptake dynamics. Univ. Florida, Gainesville, Ph.D. Diss.

Mattos, D., D.A. Graetz, and A.K. Alva. 2003. Biomass distribution and nitrogen partitioning in citrus trees on a sandy Entisol. Soil Sci. Soc. Amer. J. 67:555563.

Miller, D.E. 1967. Available water in soil as influenced by extraction of soil water by plants. Agron. J. 59:420-423.

Morgan, K.T., T.A. Obreza, and J.M.S Scholberg. 2007. Orange tree fibrous root length density distribution in space and time. J. Amer. Soc. Hort. Sci. $132: 262-269$.

Morgan, K.T., T.A. Obreza, J.M.S. Scholberg, L.R. Parsons, and T.A. Wheaton. 2006. Citrus water uptake dynamics on a sandy Florida Entisol. Soil Sci. Soc. Amer. J. 70:90-97.

Morgan, K.T., A.W. Schumann, W.S. Castle, E.W. Stover, D. Kadyampakeni, P. Spyke, F.M. Roka, R. Muraro, and R.A. Morris. 2009. Citrus production systems to survive greening: Horticultural practices. Proc. Florida State Hort. Soc. 122:114-121.

Nappi, P., R. Jodice, A. Luzzati, and L. Corino. 1985. Grapevine root-system and VA mycorrhizae in some soils of Piedmont (Italy). Plant Soil 85:205-210.

National Institute of Health. 2009. Image processing and analysis in Java. 10 Sept. 2009. <http://rsb.info.nih.gov/ij/>.

Obreza, T.A. and D.J. Pitts. 2002. Effective rainfall in poorly drained microirrigated citrus orchards. Soil Sci. Soc. Amer. J. 66: 212-221.

Obreza, T.A. and M.E. Collins. 2008. Common soils used for citrus production in Florida. Univ. Florida Coop. Ext. Serv. SL. 193.

Paramasivam, S., A.K. Alva, and A. Fares. 2000. An evaluation of soil water status using tensiometers in a sandy soil profile under citrus production. Soil Sci. 165:343353.

Parsons, L.R. and K.T. Morgan. 2004. Management of microsprinkler systems for Florida citrus. Univ. Florida Coop. Ext. Serv. HS. 958

Schumann, A.W., J.P. Syvertsen, and K.T. Morgan. 2009. Implementing advanced citrus production systems in Florida-Early results. Proc. Florida State Hort. Soc. 122:108-113

Stevens, R. and T. Douglas. 1994. Distribution of grapevine roots and salt under drip and full- ground cover microjet irrigation systems. Irr. Sci. 15:147-152.

Tennant, D. 1975. A test of a modified line intersection method of estimating root length. J. Ecol. 63:995-1001.

Tinker, P.B. and P.H. Nye. 2000. Solute movement in the rhizosphere. Oxford Univ. Press, New York, NY.

University of Florida. 2007. Florida soil characterization data. 2 Oct. 2013. $<$ http://soils.ifas.ufl.edu/flsoils/>.

University of Florida. 2013. Florida Automated Weather Network. 20 Sept. 2013. <http://fawn.ifas.ufl.edu/>

van Genuchten, M.Th. 1980. A closedform equation for predicting the hydraulic conductivity of unsaturated soils. Soil Sci. Soc. Amer. J. 44:892-898.

Zhang, M., A.K. Alva, and Y.C. Li. 1998. Fertilizer rates change root distribution of grapefruit trees on a poorly drained soil. J. Plant Nutr. 21:1-11.

Zhang, M., A.K. Alva, Y.C. Li, and D.V. Calvert. 1996. Root distribution of grapefruit trees under dry granular broadcast vs. fertigation method. Plant Soil 183:7984. 